\title{
UPAYA ORANG TUA MEMBINA PENDIDIKAN AGAMA ISLAM ANAK DI DUSUN EMBUN PAGI JORONG PADANG GALANGGANG
}

\author{
Pardi Ramadhan, M. Isnando Tamrin, Alimir, Supriadi \\ Institut Agama Islam Negeri Bukittinggi \\ E-mail: pardiramadhan98@gmail.com, bang.is1983@gmail.com, alimir.mpdi@gmail.com, \\ supriadi@iainbukittinggi.ac.id
}

\author{
How to Cite: \\ Ramadhan.P, Tamrin, M.I., Alimir, Supriadi. (2021). Upaya Orang Tua Membina Pendidikan Agama Islam Anak di Dusun \\ Embun Pagi Jorong Padang Galanggang. Fitrab: Journal of Islamic Education, 2(2), 170-183.
}

\begin{abstract}
ARTICLE HISTORY
Received : 30 November 2021

Revised : 01 February 2022

Accepted : 02 February 2022

Published : 02 February 2022
\end{abstract}

\section{KEYWORDS:}

Parents, Children, Local Wisdom, Islamic Education

\section{RIWAYAT ARTIKEL}

Diterima : 30 November 2021

Direvisi : 01 Februari 2022

Disetujui : 02 Februari 2022

Diterbitkan : 02 Februari 2022

\section{KATA KUNCI:}

Orang Tua, Anak, Kearifan Lokal, Pendidikan Islam

\begin{abstract}
This study aims to analyze the efforts of parents to foster their children's Islamic religious education. The focus of the study is on three things, namely the form of effort, supporting factors, and obstacles. This study analyzes the efforts made by parents in Embun Pagi Hamlet, Jorong, Padang Galanggang. The research method used is a descriptive study-based qualitative. Data collection techniques used are observation, interviews, and documentation studies. The data obtained were then analyzed using the Miles and Huberman technique, namely data reduction, data display, and conclusions. The results of the study explain that the form of efforts taken are involving children in nonformal religious education, fostering children's religious practices at home, involving children in religious traditions based on local wisdom, familiarizing children to grow up in the surau. The supporting factors for the implementation and success of these efforts are the high motivation and expectations of parents for their children, coupled with a religious village environment. However, there are also inhibiting factors, namely the busyness of parents at work which is an obstacle to not being able to fully control the religious development of children.
\end{abstract}

\section{ABSTRAK}

Penelitian ini bertujuan untuk menganalisis upaya orang tua membina pendidikan agama Islam anaknya. Fokus kajian pada tiga hal yakni bentuk upaya, faktor pendukung, dan penghambat. Penelitian ini mengganalisis upaya yang dilakukan orang tua di Dusun Embun Pagi Jorong Padang Galanggang. Metode penelitian yang digunakan ialah kualitatif berbasis studi deskriptif. Teknik pengumpulan data yang digunakan ialah observasi, wawancara, dan studi dokumentasi. Data yang diperoleh kemudian dianalisis menggunakan teknik Miles dan Huberman, yakni reduksi data, penampilan data, dan penarikan kesimpulan. Hasil penelitian menjelaskan bahwa bentuk upaya yang dilakukan ialah mengikutsertakan anak pada pendidikan agama non formal, membina pengamalan agama anak di rumah, mengikutsertakannya dalam tradisi keagamaan berbasis kearifan lokal, membiasakan anak tumbuh di surau. Adapun faktor pendukung terlaksananya upaya tersebut yakni tingginya motivasi dan harapan orang tua terhadap pendidikan anaknya, selain itu didukung oleh lingkungan desa yang religius. Faktor penghambatnya yakni kesibukan orang tua bekerja menjadi penghambat untuk tidak sepenuhnya dapat mengontrol perkembangan agama anak. 
PENDAHULUAN

Melalui pendidikan seseorang akan mempunyai pengetahuan, wawasan dan mampu meningkatkan sumber daya manusia yang menjadi pendukung dalam mencapai suatu tujuan. (Shufa, 2018). Salah satu cara dalam meningkatkan sumber daya manusia tersebut adalah melalui pendidikan. Pendidikan secara harfiyah adalah usaha sadar yang dilakukan oleh pendidik terhadap peserta didik, untuk mewujudkan tercapainya perubahan tingkah laku, budi pekerti, keterampilan dan kepintaran secara intelektual, emosional dan spiritual. (Almasri, 2017). Undang-undang Sistem Pendidikan Nasional No 20 Tahun 2003 Pasal 3, menyatakan bahwa tujuan pendidikan nasional yaitu berkembangnya potensi peserta didik agar menjadi manusia yang beriman dan bertaqwa kepada Tuhan Yang Maha Esa, berakhlak mulia, sehat, berilmu, cakap, kreatif, mandiri, dan menjadi warga negara yang demokratis serta bertanggung jawab. Untuk mencapai itu semua maka diperlukan tanggung jawab jawab bersama antara keluarga, sekolah, dan masyarakat. (Syahraeni, 2015).

Selain itu, pendidikan juga memiliki peranan penting dalam membentuk generasi mendatang. Dengan pendidikan diharapkan dapat menghasilkan manusia berkualitas, bertanggung jawab dan mampu mengantisipasi masa depan. Pendidikan dalam maknanya yang luas senantiasa menstimulir, menyertai perubahan-perubahan dan perkembangan umat manusia. Selain itu, upaya pendidikan senantiasa menghantar, membimbing perubahan dan perkembangan hidup serta kehidupan umat manusia. (Taubah, 2016).

Berkaitan dengan itu umat Islam memiliki konsep pendidikan tersendiri. Dalam Islam tujuan pendidikan untuk membentuk pribadi muslim seutuhnya, mengembangkan seluruh potensi manusia baik berbentuk jasmaniyah dan rohaniyah, menumbuh suburkan hubungan harmonis setiap pribadi dengan Allah Swt, manusia dan alam semesta.(Fokalia, 2020). Dengan demikian pendidikan Islam itu berupaya untuk mengembangkan individu seutuhnya, maka sudah sewajarnya untuk dapat memahami hakikat pendidikan Islam itu bertolak dari pemahaman terhadap konsep manusia menurut Islam. (Evi Aeni Rufaedah, 2020). Peraturan Menteri Agama Republik Indonesia No. 13 tahun 2014 pasal 1 tentang pendidikan keagamaan Islam menyatakan bahwa pendidikan keagamaan Islam adalah pendidikan yang mempersiapkan peserta didik untuk dapat menjalankan peranan yang menuntut penguasaan pengetahuan tentang ajaran agama Islam dan/atau menjadi ahli ilmu agama Islam dan mengamalkan ajaran agama Islam.

Pendidikan agama Islam yang diperoleh anak tentunya tidak terlepas dari peran orang tua di rumah. Orang tua merupakan orang yang lebih tua atau orang yang dituakan. Namun umumnya di masyarakat pengertian orang tua itu adalah orang yang telah melahirkan kita yaitu ibu dan bapak. Karena orang tua adalah pusat kehidupan rohani anak, maka setiap reaksi emosi 
anak dan pemikirannya dikemudian adalah hasil dari ajaran orang tuanya tersebut. Sehingga orang tua memegang peranan yang penting dan amat berpengaruh atas pendidikan anak-anak. (Padjrin, 2016). Kedua orang tua harus memahami dengan baik kewajiban dan tanggung jawab sebagai orang tua. Orang tua tidak hanya sekedar membangun silaturrahim dan melakukan berbagai tujuan berkeluarga, seperti reproduksi, meneruskan keturunan, menjalin kasih sayang dan sebagainya. Akan tetapi juga membina dan mengarahkan anak-anaknya agar mampu kelak melaksanakan tugasnya sebagai manusia yang memang dikehendaki oleh Allah Swt. (Roesli et al., 2018).

Tugas orang tua sangat urgen, yakni memberi perhatian, bimbingan, arahan, motivasi, penanaman nilai, dan melaksanakan proses pendidikan yang berkelanjutan (continues progress) guna melahirkan generasi penerus (keturunan) yang cerdas dan berakhlak (berbudi pekerti yang baik). (Adawiyah, 2016). Baik di mata orang tua dan masyarakat. Al-Gazali menyebutkan bahwa, anak adalah amanah Tuhan untuk kedua orang tuanya. Hatinya suci dan bersih dari segala goresan dan bentuk. Kedua orang tuanyalah yang harus menanggung resiko yang timbul akibat perbuatannya yaitu bertanggung jawab atas pemeliharaan dan pendidikan anak-anaknya sebagai amanat dari Tuhan. (Kuswandi, 2019). Perintah tentang tanggung jawab orang tua di jelaskan Allah Swt melalui Firman-Nya yang terdapat di dalam Surah:
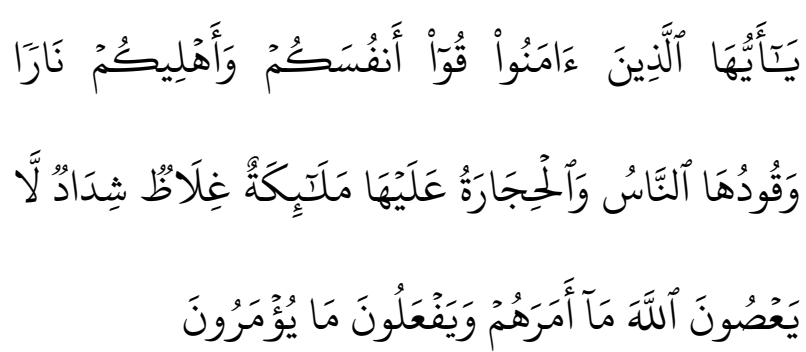

Artinya: Hai orang-orang yang beriman, pelibaralah dirimu dan keluargamu dari api neraka yang bahan bakarnya adalah manusia dan batu; penjaganya malaikat-malaikat yang kasar, keras, dan tidak mendurbakai Allah terhadap apa yang diperintabkanNya kepada mereka dan selalu mengerjakan apa yang diperintabkan. (Q.S. at-Tahrim [66]: 6)

Demikianlah lingkungan keluarga sebagai lingkungan pendidikan yang pertama yang perlu diperhatikan dalam mendidik generasi muda. Keberhasilan dalam lingkungan pendidikan keluarga merupakan salah satu modal awal dalam melakukan pendidikan selanjutnya. Suasana keluarga yang kondusif akan menghasilkan warga masyarakat yang baik karena di dalam keluargalah seluruh anggota keluarga belajar berbagai dasar kehidupan bermasyarakat. Pembinaan terhadap anak secara dini dalam keluarga merupakan suatu yang sangat mendasar. Pendidikan agama, budi pekerti, dan tatakrama yang diberikan secara dini di rumah serta teladan dari kedua orang tuanya akan membentuk kepribadian dasar dan kepercayaan diri anak yang akan mewarnai perjalanan hidup selanjutnya.(Sulistyoko, 2018).

Berkaitan dengan pendidikan dasar anak di keluarga Nashih Ulwan mengidentifikasi aspek-aspek pendidikan yang harus diketahui dan dilaksanakan oleh oran tua dalam mendidik 
anak. Adapun aspek-aspek pendidikan tersebut meliputi pendidikan keimanan pada anak, pendidikan moral (akhlak) pada anak, pendidikan intelektual pada anak, pendidikan jasmani pada anak, pendidikan psikologi pada anak, pendidikan sosial pada anak dan pendidikan seksual pada anak. (Ulwan, 2017).

Penjelasan ragm teori di atas memberikan penegasan bahwa pendidikan anak menjadi sangat penting untuk diperhatikan oleh keluarga khususnya oleh kedua orang tuanya. Sebab tak dapat dipungkiri bahwa banyak permasalahan pendidikan yang dialami saat ini bermula dari permasalahan kurangnya perhatian keluarga terhadap pendidikan anaknya. Seperti observasi awal yang peneliti lakukan di dusun Embun Pagi Jorong Padang Galanggang, pada tanggal 21 Januari 2021, bahwa tampak kurangnya perhatian orang tua terhadap pendidikan anaknya, hal itu terlihat dari minimnya jumlah anak yang mengikuti pembelajaran di lembaga Taman Pendidikan AlQur'an (TPA) yang ada di dusun tersebut. Selain itu kurangnya perhatian juga terlihat dari minimnya pegetahuan anak tentang pengamalan agama dalam keseharian, seperti masih banyaknya anak yang tidak mampu melaksanakan shalat dengan benar, banyaknya anak yang belum mampu membaca Al-Qur'an, dan banyak anak yang terlihat lebih menghabiskan waktunya bermain ketimbang menimba ilmu di surau. Bahkan ada pula ditemukan seorang anak yang berkata-kata tidak baik dihadapan orang tuanya, akan tetapi orang tuanya terlihat tidak begitu menghiraukan seakan-akan hal tersebut sudah biasa. Hal ini diduga terjadi karena kurangnya perhatian dan kepedulian orang tua terhadap pendidikan agama Islam yang seharusnya orang tualah yang menjadi pendidik pertama dan utama dalam keluarga terutama bagi anak-anaknya.

Berkaitan dengan itu Dusun Embun Pagi Jorong Padang Galanggang, dikenal sebagai daerah yang kuat dengan tradisi keagamaanya, dusun yang memang masih memegang kuat nilai-nilai luhur yang diwariskan oleh leluhur mereka. Atas dasar itu seyogyanya pendidikan Islam yang ada di dusun ini terlaksana dengan baik. Memang demikian halnya, di samping adanya orang tua yang kurang perhatian ada juga orang tua yang sangat peduli terhadap pendidikan agama Islam anaknya, bahkan diselasela kesibukan mereka masih meluangkan waktu untuk memberikan pendidikan agama Islam bagi anaknya.

Hasil pengamatan awal peneliti, upaya pembinaan agama anak yang dilakukan di dusun tersebut memiliki keunikan dan ciri khas tersendiri yang tak dimiliki di daerah lain. Letak keunikannya pada ciri khas kearifan lokal, adat istiadat dan budaya yang melekat. Ragam tradisi memang kerap dilakukan di dusun tersebut, walau pada awalnya tidak bertujuan langsung pada dunia pendidikan anak, namun muatan pendidikan agama Islam dari tradisi itu menjadi begitu penting bagi orang tua untuk mengikutsertakan anaknya dalam kegiatan tersebut. 
Intinya banyak upaya yang dilakukan oleh orang tua dalam rangka membina pendidikan agama Islam bagi anak di antaranya dengan memberikan pendidikan ibadah seperti ibadah shalat, mengajarkan anak mengaji di rumah. Kemudian bisa juga memberikan pendidikan akhlak kepada anak melalui keikutsertaanya dalam kegiatan-kegiatan yang dilakukan disurau. Semua kegiatan itu tentu menjadi unik utuk diteliti, dan menjadi distingsi dari penelitian tentang pembinaan agama anak di daerah-daerah lainnya.

Beranjak dari permasalahan tersebut, maka peneliti ingin menganalisis lebih lanjut, mengapa hal tersebut bisa terjadi dan bagaimana sebenarnya upaya orang tua dalam membina pendidikan agama Islam bagi anaknya. Maka fokus dan tujuan penelitian ini pada tiga hal yakni (1) Bentuk upaya pembinaan pendidikan agama Islam yang dilakukan orang tua, (2) Faktor pendukung keberhasilan upaya pembinaan pendidikan agama Islam, dan (3) faktor penghambat keberhasilan upaya pembinaan pendidikan agama Islam.

Untuk mengetahui distingsinya, berikut dieksplorasi ragam penelitian terdahulu yang relevan dengan penelitian ini di antaranya penelitian tentang upaya orang tua dalam pembinaan ibadah shalat anak (Sofia, 2020), kemitraan guru dan orang tua dalam pembinaan agama anak (Abdullah, 2018), upaya orang tua dalam pembinaan ibadah anak di lingkungan keluarga (Sepriyanto et al., 2021), peran keluarga bagi penididikan agama anak (Zulhaini, 2019), pendidikan agama anak di lingkungn keluarga masyarakat Aceh (Rahmi, 2018), pendidikan agama anak di keluarga dan signifikansinya terhadap pembentukan karakter (Haris \& Auliya, 2019), penguatan pendidikan agama anak di lingkungan keluarga (Solihah, 2020), pendidikan agama anak pada keluarga milenial (Khamim, 2019), teori dan tanggung jawab orang tua dalam pendidikan agama anak, (Jailani, 2014), pengaruh lingkungan keluarga terhadap motivasi belajar pendidikan agama Islam anak (Zuhrotunnisak, 2018). Berdasarkan ragam penelitian terdahulu tersebut dapatlah dipertegas distingsi dari penelitian ini dibandingan dengan penelitian lainnya. Jika penelitian lainnya terfokus pada upaya yang dilakukan orang tua semata, berbeda dengan penelitian ini yang fokus penelitiannya pada upaya orang tua yang mengadopsi dan mengkolaborasikan tradisi kearifan lokal sebagai upaya pembinaan pendidikan agama Islam anak.

Penelitian ini akan menganalisis lebih mendalam tentang upaya yang dilakukan orang tua dalam lingkungan keluarga, dan upaya orang tua mengadopsi dan mengkolaborasikan upaya pembianaannya lewat tradisi berbasis kearifan lokal. Hal ini tentu menjadi sumbangsih penting terutama dalam melahirkan ragam metode pendidikan anak di keluarga berbasis kearifan lokal.

\section{KAJIAN TEORI}

Dalam Kamus Besar Bahasa Indonesia upaya diartikan sebagai usaha, akal, ikhtiar (untuk mencapai suatu maksud, memecahkan persoalan, mencari jalan keluar dan sebagainya). 
Dalam arti lain upaya adalah usaha (syarat untuk menyampaikan suatu maksud). Dalam penelitian ini upaya yang dimaksud ialah usaha berbentuk membina atau mendidik yang dilakukan oleh orang tua terhadap anaknya. Upaya dalam pengertian ini menunjukkan makna yang berkelanjutan dalam arti bukan upaya yang sekali saja melainkan upaya yang terus menerus dilakukan.

Tugas sebagai orang tua merupakan suatu tugas yang luhur dan berat. Sebab ia tidak sekedar bertugas menyelamatkan nasib anakanaknya dari bencana hidup di dunia. Namun jauh dari itu ia bisa memikul amanat untuk menyelamatkan mereka dari siksa neraka di akhirat dimana anak merupakan amanat Tuhan bagi kedua orang tuanya. Setiap orang tua, para pendidik maupun para guru pada hakekatnya adalah mengemban amanat Allah. Karena mereka akan dimintai pertanggung jawaban oleh Allah tentang bagaimana keadaan pendidikan anak-anaknya. Dalam melaksanakan amanat tersebut, orang tua dan masyarakat harus senantiasa menyesuaikan diri dengan tahapan pertumbuhan dan perkembangan anak sesuai dengan usianya baik jasmani, kecerdasan, rohani dan sosial, sehingga dengan tahapan tersebut akan tumbuh kesadaran anak dan kewajibankewajibannya yaitu kepada Allah, diri sendiri, orang tua dan masyarakat.

Pendidik menurut Islam adalah setiap individu yang bertanggung jawab terhadap perkembangan peserta didik. Pendidikan pertama dan utama adalah keluarga. Tugas mendidik sebenarnya berada di pundak orang tua sebab dari merekalah proses kelahiran anak terjadi, orang tua adalah pihak yang paling dekat dengan anak, dan paling berkepentingan terhadap anak-anaknya yaitu anak sebagai generasi penerus keturunan, anak merupakan kebanggaan dan belaian kasih orang tua dan doa anak merupakan investasi bagi orang tua setelah mereka wafat. Oleh karena itu, orang tua diberi amanah dan tanggung jawab untuk mengembangkan anak-anaknya.

Membina menurut bahasa berawal dari kata dasar "bina" yang berasal dari bahasa Arab "Bana" yang berarti membangun, mendirikan. Berdasarkan Kamus Besar Bahasa Indonesia (KBBI) membina adalah suatu kegiatan yang dilakukan secara efektif untuk memperoleh hasil yang baik dan mempertahankan serta menyempurnakan apa yang telah ada sesuai dengan yang diinginkan atau diharapkan.

Dari penjelasan di atas yang dimaksud membina dalam hal ini yaitu memberikan pendidikan agama Islam bagi anak yang dilakukan oleh orang tua yaitu bapak sebagai orang tua laki-laki dan ibu sebagai orang tua perempuan.

Dalam penelitian ini pembinaan yang dimaksud ialah pembinaan diri anak yang menyangkut aspek spritual, kognitif, afektif, dan psimotorik pada nilai-nilai ajaran Islam. Secara teoritis pembinaan paling awal dilakukan oleh orang tua dalam lingkungan keluarga. Bahkan dalam beberapa pendapat dikatakan bahwa keluarga merupakan lembaga pendidian pertama 
bagi anak. Walau dikatakan demikian tetapi secara fenomena memang tidak selamanya menunjukkan demikian. Dengan berbagai kesibutkan dan pengaruh lain, banyak anak yang terabaikan pendidikan agamanya.

Setiap daerah tentu memiliki keunikan atau ciri khas masing-masing, dalam istilah modern hal ini disebut dengan kearifan lokal. Indonesia yang daerahnya dikenal kaya akan budaya dan adat tentu melahirkan ragam tradisi dan kebudayaan. Ragam tradisi dan kebudayaan tentu mempengaruhi sendi-sendi kehidupan masyarakaat setempat termasuklah sendi pendidikan. Ragam tradisi dan kebudayaan memang erat kaitannya dengan nilai-nilai pendidikan, maka tak heran banyak masyarakat yang menjadikan tradisi atau kebudayaan setempat sebagai wadah pendidikan anak, termasuk dalam hal ini pendidikan agama anak. (Kurnianto, 2019).

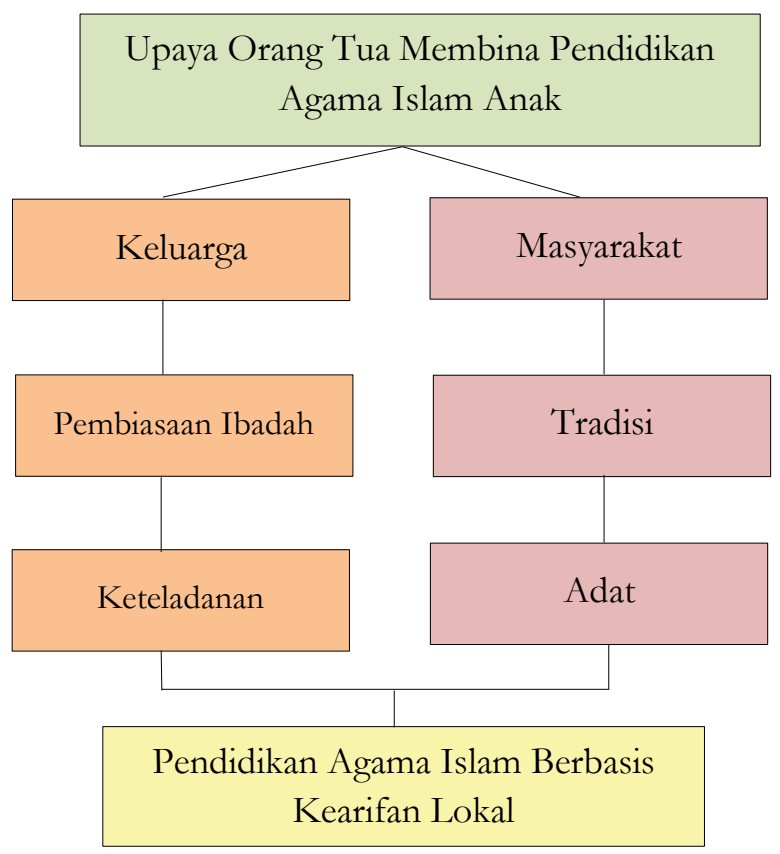

Bagan 1. Skema Pembinaan Agama Anak

\section{METODE PENELITIAN}

Jenis penelitian ini menggunakan pendekatan kualitatif, berbasis studi deskriptif. Berawal dari minimnya pengetahua agama anak dan uniknya upaya yang diterapkan di dusun Embun Pagi Jorong Padang Galanggang menjadi alasan utama di tetapkannya pendekatan studi deskriptif. Penelitian ini dilaksanakan di dusun Embun Pagi Jorong Padang Galanggang dengan alasan karena ciri khas kearifan lokal yang memiliki keunikan yang tidak dimiliki di daerah lain.

Informan pada penelitian ini adalah orang tua, tokoh adat dan agama yang berada di dusun tersebut. Penelitian ini dilaksanakan selama 6 bulan yang terhitung dari Januari sampai pada Juni 2021. Dalam hal pengumpulan data teknik yang digunakan ialah observasi, wawancara, dan dokumentasi. Observasi digunakan untuk mengamati secara langsung dan mendalam tentang upaya orang tua dalam membina pendidikan agama Islam anak dan aktivitas pendidikan anak berbasis kearifan lokal. Wawancara untuk menggali informasi lebih dalam terkait dengan pengamatan yang telah dilakukan. Dokumentasi dilakukan untuk menganalisis segala dokumen yang berkaitan dengan akivitas pendidikan yang dilaksanakan di dusun tersebut. Analisis data menggunakan teknik Miles dan Huberman yang terdiri dari reduksi data, penampilan data, dan penarikan kesimpulan. Selanjutnya untuk menjamin keabsahan data yang telah diperoleh dilakukan upaya dengan teknik member crosscheck dan trianggulasi data. 


\section{HASIL DAN PEMBAHASAN PENELITIAN}

Pemaparan hasil penelitian akan terlebih dahulu menjelaskan bentuk-bentuk upaya yang dilakukan orang tua dalam membina pendidikan agma Islam anak di dusun Embun Pagi Jorong Padang Galanggang, bentuk yang akan dipaparkan ini tidak hanya bentuk yang ada di lingkungan keluarga akan tetapi juga yang ada pada lingkungan masyarakat.

\section{Bentuk Upaya Orang Tua Membina Pendidikan Agama Islam Anak}

Dalam hal membina pendidikan agama Islam anak terdapat beberapa bentuk upaya yang dilakukan orang tua, bentuk upaya ini sebenarnya tidak semuanya murni aktivitas orang tua, terdapat beberapa aktivitas yang juga berasal dari tradisi setempat, namun dalam hal ini orang tua mengupayakan dan mengontrol anaknya agar ikut serta dalam kegiatan tersebut. Bentuk upaya yang dimaksud sebagai berikut:

\section{Membina Pengamalan Agama Anak di Rumah}

Upaya ini lazim dilakukan oleh setiap orang tua di rumah. Pengamalan agama yang dimaksud seperti mengajarkan anak tentang bacaan dan gerakan shalat, mengajarkan tentang doa-doa keseharian, dan mengajarkan tentang puasa, dan ibadah lainnya. Pembinaan pengamalan agama anak ini dilakukan orang tua karena memang secara alokasi waktu pelajaran agama di sekolah tidak memungkinkan untuk mengontrol secara penuh tentang pengamalan agama anak. Sehingga orang tua perlu untuk memberikan tambahan ataupun penyempurnaan melalui pembinaan di rumah.

Hasil wawancara dengan beberapa orang tua dapat disimpulkan bahwa mereka mengaku tidak memiliki materi ataupun metode khusus dalam membina pengamalan agama anak. Menurut penuturan orang tua semua dilakukan berdasarkan pemahaman orang tua semata. Dalam arti apa yang mereka ketahui itulah yang diajarkan orang tua pada anaknya. Metode yang dipergunakan pun terkesan tidak ada kekhususan, hanya sekedar metode demonstrasi langsung dari orang tua.

Pada bentuk upaya ini memang tidak ada yang khusus, artinya bentuk upaya ini juga mungkin dilaksanakan di daerah lain. Hanya saja pada daerah ini pembinaan pengamalan agama anak dilakukan dengan kecederungan pada kemampuan melaksanakan perintah agama seperti shalat, puasa, membaca Al-Qur'an, berwudhu, dan sebagainya. Sedangkan untuk urusan yang diluar aktivitas ibadah biasanya tidak dilakukan di lembaga pendidikan non formal, di TPA, madrasah atau juga di surau.

Hasil pengamatan peneliti, tampak bahwa pembinaan ini lazimnya dilakukan setelah shalat magrib, dilakukan disela-sela orang tua beristirahat setelah seharian bekerja. Orang tua biasanya duduk secara bersama diruang tamu berasama dengan istri dan anak-anaknya dan disaat itu laazimya orang tua memberikan wejangan dan pembinaan agama kepada anakanaknya. Bahkan sering terjadi pada waktu ini 
sang anak atau istri melakukan tanya jawab seputar hal-hal keagamaan. Jika orang tua tidak ada, kegiatan seperti ini juga biasanya dilakukan oleh kakek atau neneknya.

\section{Mengikutsertakan Anak pada Pendidikan Agama Non Formal}

Upaya lain yang dilakukan orang tua untuk membina pendidikan agama anak adalah dengan mengikutsertakannya dalam pendidikan agama yang bersifat non formal, di antara lembaga pendidikan non formal yang ada di dusun tersebut ialah Taman Pendidikan Al-Qur'an (TPA) dan Madrasah Diniyah Awaliyah (MDA), dua lembaga ini menjadi lembaga pendidikan yang mengajarkan pendidikan agama dasar kepada anak. Materi yang diajarkan bersifat suplemen terhadap materi agama Islam yang telah diajarkan di sekolah. Namun berdasarkan yang penulis amati, perbedaanya dengan sekolah formal, lembaga pendidikan agama non-formal menggunakan 'arab melayu' sebagai bahasa pengantaar bukunya.

Kurikulum yang diajarkan di lembaga pendidikan formal ini adalah Akidah akhlak, Fikih, Al-Qur'an Hadis, Sejarah kebuayaan Islam, Bahasa Arab (muthalaah dan Mubadasab), dan pembelajaran tajwid AlQur'an. Target utama dari taman pendidikan Al-Qur'an adalah agar anak-anak di dusun Embun Pagi Jorong Padang Galanggang tidak buta aksara Al-Qur'an. Sebagaimana yang memang menjadi kekhawatiran tokoh masyrakat setempat, sehingga dibangunlah madrasah dan TPA tersebut.

Wawancara dengan beberapa orang tua di desa tersebut dapat tersimpulkan bahwa motivasi mereka untuk mengikutsertakan anaknya mengenyam pendidikan agama di lembaga pendidikan agama non formal tersebut ialah agar anak mereka mendapatkan pengetahuan agama tambahan dari sekolah, di samping itu mereka juga mengaku bahwa ketidakmampuan mereka untuk mengajarkan pelajaran agama juga menjadi alasan mengapa mereka mengikutsertakan anak mereka pada lembaga pendidikan agama non formal.

\section{Mengikutsertakannya dalam Tradisi}

\section{Keagamaan Berbasis Kearifan Lokal}

Upaya lain yang dilakukan orang tua untuk membina pendidikan anaknya aadalah mengikutsertakan anaknya dalam ragam tradisi keagamaan berbasis kearifan lokal, seperti mkan bajambo, wiridan, yasinan, maulid Nabi, isra' mi'raj. Dan sebagainya. Perayaan ini mungkin ada di setiap daerah akan tetapi di setiap daerah tentu merayakannya dengan cara yang berbeda. Seperti yasinan mungkin di daerah lain dilakukan setiap malam jumat, akan tetapi di dusun ini dilakukan setiap kali syukuran akan keberhasilan atau sejenisnya. Walaupun beberapa orang juga melakukannya setiap malam jumat.

Selain itu seperti kita melaksanakan perayaan mauled atau isra' mi'raj laimnya masyarakat setempat memasak masakan khas 
seperti lamang, katupek, lapek, dan sebagainya. Masakan itu di santap bersama namun sebelumnya dilakukan pembacaan ayat-ayat suci Al-Qur'an, dzikir bersama, shalawatan bersama dan sebagainya. Menurut penuturan tokoh adat atau agama yang diwawancarai tradisi itu merupakan warisan para leluhur yang perlu untuk dilestarikan, karena di dalamnya sarat akan nilai-nilai kebaikan yang dapat mengubah tatanan kehidupan bermasyarakat agar lebih kompak dan bersatu. Bahkan bukan hanya itu ketaatan kepada sang pencipta pun akan tercipta dari ragam tradisi tersebut.

Keinginan orang tua agar anaknya kelak dapat meneruskan tradisi warisan tersebutlah yang menjadi motivasi utama orang tua di dusun tersebut mengikutsertakan anaknya dalam ragam tradisi keagamaan di dusun tersebut. Tidak hanya itu tetapi dengan mengikutsertakannya anak-anak mereka diharapkan memiliki pengetauan dan pengamalan agama yang baik. Penuturan beberapa orang tua mengatakan demikian "setidaknya dengan mengikuti kegiatan itu, anak-anak dapat mencontoh apa yang dilakukan oleh para orang tua, sehingga lama-kelamaan mereka akan juga menjadi orang yang shalih seperti orang tua tersebut".

\section{Membiasakan Anak datang ke Surau}

Bentuk upaya terakhir dari pembahasan ini adalah mengikutsertakan anak untuk aktif di Surau. Surau merupakan tempat ibadah kecil yang hampir mirip dengan masjid seara fungsi, akan tetapi di tanah Minang surau menjadi tempat berkupul para kaum pria muda terutama dalam berinteraksi dan bergaul bersama.(Pajri, 2017). Dikarenakan surau sebagai tempat beribadah tentu akan banyak hal kegiatan ibadah yang dilakukan oleh anak yang datang ketempat itu, bukan hanya itu tapi pembicaraan atau diskusi kecil berkaitan dengan agama atau ibadah juga sering terjadi di surau. (Afdayeni, 2018).

Lazimnya surau dipimpin oleh seorang imam atau ustaz, maka dari itu imam atau ustaz tersebutlah yang melakukan pembinaan agama kepada jamaahnya. Orang tua mengupayakan anaknya untuk dapat aktif mengikuti ragam kegiatan yang diselenggarakan di surau, dengan begitu anak akan tumbuh dengan nuansa keislaman. (Azra, 2017).

Berdasarkan ragam bentuk upaya yang dilakukan oleh orang tua terhadap pendidikan agama Islam anaknya pada akhir bermuara pada kepeduliannya terhadap pengamalan agama anak. Sebenarnya secara teoritis pendidikan Islam tidak hanya menyangkut untuk urusan ibadah semata akan tetapi juga menyangkut urusan lain yang tak kalah pentingnya. Seperti urusan (1) pendidikan keimanan pada anak yang bertujuan untuk mengikat anak dengan dasardasar iman, rukun Islam dan dasar-dasar syariah, sejak anak mulai mengerti dan dapat memahami sesuatu. (2) pendidikan moral (akhlak) pada anak yang bertujuan untuk membentuk akhak dan kepribadian anak sesuai dengan yang diamanahkan oleh Islam. (3) pendidikan 
intelektual kepada anak, yang bertujuan untuk pembentukan pola pikir anak dengan segala sesuatu yang bermanfaat dengan ilmu pengetahuan melalui pengajaran. (4) pendidikan jasmani pada anak, yang bertujuan menjaga kebersihan diri dan kebersihan lingkungan sekitar. (5) pendidikan psikologi pada anak, yang bertujuan agar anak memiliki sikap berani, suka berbuat baik, bertanggung jawab dan mampu menahan diri ketika marah. (6) pendidikan sosial pada anak, yang bertujuan agar di dalam lingkungan masyarakat nanti anak terbiasa menjalankan adab sosial yang baik, keseimbangan akal yang matang dan memiliki tindakan yang bijaksana. (6) pendidikan seksual pada anak, yang bertujuan agar memberikan penyadaran dan penerangan kepada orang tua tentang masalah-masalah yang berkaitan dengan seksual dan lawan jenis.

Namun tampaknya semua jenis pendidikan tersebut tidak sepenuhya tersentuh oleh ragam kegiatan berbasis kearifan lokal tersebut. Jika dikatakan terkait memang bisa saja dikaitkan, akan tetapi memang tidak secara khusus tradisi itu untuk masing-masing jenis pendidikan yang telah disebutkan sebelumnya. Jika pun ada tentu tidak tertata dengan baik.

\section{Faktor Pendukung Upaya Orang Tua} Membina Pendidikan Agama Islam Anak

Faktor pendukung merupakan alasanalasan atau sebab-sebab seseorang melakukan sesuatu. Dalam hal ini faktor pendukung yang peneliti maksud yaitu faktor pendukung upaya orang tua dalam membina pendidikan agama Islam bagi anaknya. Dapat disimpulkan bahwa motivasi atau keinginan dari orang tua agar anaknya menjadi seorang yang paham akan ilmu agama dan menjadi seorang yang memiliki pengetahuan, wawasan, serta pengamalan ibadah yang baik menjadi faktor pendukung terlaksananya upaya orang tua dalam membina pendidikan agama Islam bagi anaknya.

Tidak hanya itu, lingkungan masyrakat yang religi menjadi faktor pendukung juga. Sebab dengan adanya itu anak akan sangat mudah untuk diarahkan, dan orang tua pun dengan sendirinya akan menyadari bahwa betapa perlunya anak untuk dekat dengan pengamalan agama. Dukungan masyrakat berupa terlaksananya tradisi keagamaan menjadi faktor pendukung secara tidak langsung. Anak-anak secara tidak langsung memiliki wadah untuk berkumpul menyibukkan diri dengan ragam kegiatan yang dapat meningkatkan pemahaman agamanya.

\section{Faktor Penghambat Upaya Orang Tua Membina Pendidikan Agama Islam Anak}

Faktor penghambat merupakan alasanalasan atau sebab-sebab seseorang tidak atau belum melakukan sesuatu. Dalam hal ini faktor penghambat yang peneliti maksud yaitu faktor penghambat upaya orang tua dalam membina pendidikan agama Islam bagi anaknya. Dapat disimpulkan bahwa latar belakang pendidikan orang tua, kesibukan orang tua sehari-hari dalam bekerja dan lingkungan pergaulan orang tua 
menjadi faktor penghambat upaya orang tua dalam membina pendidikan agama Islam bagi anaknya.

Orang tua yang memiliki latar belakang pendidikan rendah cenderung menganggap bahwa pendidikan agama tidak menjadi kebutuhan penting bagi anaknya. Sedangkan kesibukan orang tua dalam bekerja membuatnya tidak memiliki waktu untuk mengontrol perkembangan agama anak, bahkan di rumah yang seharusnya terlaksana pembinaan pengamalan agama menjadi tidak terlaksana karena kesibukan orang tua yang tidak sempat untuk mendidik anaknya. Tentu inilah yang menjadikan pemahaman dan pengamalan anak akan agama menjadi minim.

\section{SIMPULAN}

Berdasarkan pembahasan yang peneliti paparan di atas maka dapatlah ditarik kesimpulannya bahwa terdapat beberapa bentuk upaya yang dilakukan orang tua dalam hal pembinaan pedidikan agama Islam anaknya yakni membina pengamalan agama anak di rumah, mengikutsertakan anak pada pendidikan agama non formal, mengikutsertakannya dalam tradisi keagamaan berbasis kearifan lokal, membiasakan anak datang ke surau. Adapun faktor pendukug upaya orang tua dalam membina pendidikan agama Islam anaknya ialah adanya motivasi atau keinginan dari orang tua agar anaknya menjadi seorang yang paham akan ilmu agama dan menjadi seorang yang memiliki pengetahuan, wawasan, serta pengamalan ibadah, kemudian adanya lingkungan masyrakat yang religi, serta adanya dukungan masyrakat berupa terlaksananya tradisi keagamaan. Sedangan faktor penghambat upaya orang tua membina pendidikan agama Islam anaknya ialah latar belakang pendidikan orang tua yang rendah, kesibukan orang tua sehari-hari dalam bekerja dan lingkungan pergaulan orang tua.

\section{DAFTAR PUSTAKA}

Abdullah, A. (2018). Kemitraan Guru Pendidikan Agama Islam dan Orang Tua dalam Pembinaan Keagamaan Siswa. Kalam: Jurnal Agama dan Sosial Humaniora, 6(2), 15-30. http://journal.lsamaaceh.com/index.php/ $\mathrm{kalam} /$ article/view/45

Adawiyah, A. U. (2016). Peranan orang tua dalam pendidikan kearakter anak, masa kini (Di Lingkemgan RT 014 RW 005, Kelurahan Cipete Selatan, Kecamatan Cilandak, Jakarta Selatan). Fakultas Ilmu Tarbiyah dan Keguruan (FITK) UIN Syarif Hidayatullah Jakarta. https://repository.uinjktac.id/dspace/handle/123 456789/44203

Afdayeni, M. (2018). Dinamika Sistem Pendidikan Islam (Surau) Minangkabau Pra dan Pasca Pembaharuan. Jumal Fuaduna: Jumal Kajan Keagamaan Dan Kemasyarakatan, 1(1), 58-69. http://dx.doi.org/10.30983/fuaduna.v1i1.442

Almasri, M. N. (2017). Manajemen Sumber Daya Manusia: Imlementasi dalam Pendidikan Islam. Kutubkhanah, 19(2), 133$151 . \quad$ http://ejournal.uinsuska.ac.id/index.php/Kutubkhanah/articl e/view/2547

Azra, A. (2017). Surau: Pendidikan Islam Tradisi dalam Transisi dan Modernisasi. Kencana.

Evi Aeni Rufaedah. (2020). Peranan Pendidikan Agama dalam Keluarga Terhadap Pembentukan Kepribadian Anak-Anak. Counselia; Jurnal Bimbingan Konseling Pendidikan Islam, 1(1), 8-25. https://counselia.faiunwir.ac.id/index.php /cs/article/view/2 
Fokalia, D. (2020). Pendidikan Islam dalam Keluarga di Desa Giri Kencana Kecamatan Ketabun Kabupaten Bengkulu Utara (Studi Kasus pada Orang Tua Yang Bercerai) (pp. 35). IAIN Bengkulu.

Haris, M., \& Auliya, H. (2019). Urgensi Pendidikan Agama dalam Keluarga dan Implikasinya Terhadap Pembentukan Kepribadian Anak. Masile, 1(1), 46-64. http://jurnal.staima.ac.id/index.php/masil e/article/view/7

Jailani, M. S. (2014). Teori Pendidikan Keluarga dan Tanggung Jawab Orang Tua dalam Pendidikan Anak Usia Dini. Jurnal Pendidikan Islam, Vol 8 No 2, 246-260.

Khamim, N. (2019). Penerapan Pendidikan Agama Islam pada Keluarga Millenial. Attaqwa: Jurnal Ilmu Pendidikan Islam, 15(2), 132-142.

https://doi.org/10.54069/attaqwa.v15i2.18

Kurnianto, R. (2019). Pembelajaran Agama Islam Berbasis Budaya Lokal (Strategi Internalisasi Nilai-Nilai Pendidikan Agama Islam melalui Seni Reyog Ponorogo). Seminar Nasional Pendidikan 2015, 862-875. http://jurnal.uniyap.ac.id/jurnal/index.php /jurnalfai/article/view/496/0

Kuswandi, I. (2019). Akhlaq Education Conception of ibn Miskawaih and alGhazali and Its Relevancy to The Philosophy of Muhammadiyah Pesantren. Proceeding International Conference on Islamic Education (ICIED), 4(1), 186-197.

Padjrin, P. (2016). Pola Asuh Anak dalam Perspektif Pendidikan Islam. Jurnal Intelektualita: Keislaman, Sosial dan Sains, 5(1), 1-14. https://doi.org/10.19109/intelektualita.v5i1.720

Pajri, A. (2017). Distorsi Nilai-nilai Pendidikan Surau di Minangkabau Sumatra Barat (pp. 35). Universitas Islam Indonesia. https://dspace.uii.ac.id/handle/123456789 $/ 5052$

Rahmi, A. (2018). Pendidikan Agama Bagi Anak Dalam Keluarga di Gampong Aneuk Galong Baro, Aceh Besar. FITRAH: Jurnal
Kajian Ilmu-Imu Keislaman, 4(1), 129-140. https://doi.org/10.24952/ fitrah.v4i1.880

Roesli, M., Syafi'i, A., \& Amalia, A. (2018). Kajian islam tentang partisipasi orang tua dalam pendidikan anak. Jurnal Darussalam: Jurnal Pendidikan, Komunikasi dan Pemikiran Hukum Islam, 9(2), 332-345. https://doi.org/10.30739/darussalam.v9i2. 234

Sepriyanto, S., Hurmaini, H., \& Jaya, J. (2021). Upaya Orang Tua Dalam Pembinaan Ibadah Shalat Anak di Lingkungan Keluarga Rt 09 Kelurahan Pelabuban Dagang Kecamatan Tungkal Ulu Kabupaten Tanjung Jabung Barat Provinsi Jambi [UIN Sulthan Thaha Saifuddin Jambi]. http://repository.uinjambi.ac.id/9770/

Shufa, N. K. F. (2018). Pembelajaran Berbasis Kearifan Lokal Di Sekolah Dasar: Sebuah Kerangka Konseptual. INOPENDAS: Jurnal Ilmiah Kependidikan, 1(1), 48-53. https://doi.org/10.24176/jino.v1i1.2316

Sofia, S. (2020). Upaya Orangtua dalam Pembinaan Ibadah Shalat Pada Anak Usia Dini di Desa Balai Makam. Al-Qolam: Jurnal Dakwah dan Pemberdayaan Masyarakat, 4(1), 77-98.

http://www.journal.staihubbulwathan.id/i ndex.php/alqolam/article/view/319

Solihah, F. A. (2020). Peran Orang Tua dalam Penguatan Pendidikan Agama Islam di Lingkungan Keluarga di Desa Pujon Kidul Kecamatan Pujon Kabupaten Malang [Universitas Islam Malang]. http://repository.unisma.ac.id/handle/123 456789/1030

Sulistyoko, A. (2018). Tanggung Jawab Keluarga dalam Pendidikan Anak Di Era Kosmopolitan (Tela'ah Tafsir Kontemporer Atas Surat At-Tahrim Ayat ๑). Iqro: Joumal of Islamic Education, 1(2), 177-192. https://doi.org/10.24256/iqro.v1i2.499

Syahraeni, A. (2015). Tanggung Jawab Keluarga dalam Pendidikan Anak. Al-Irsyad Al-Nafs: Jurnal Bimbingan dan Penyuluban Islam, 2(1), 18-36. http://journal.uin-alauddin.ac.id/index.php/AlIrsyad_Al-Nafs/article/view/2560 
Taubah, M. (2016). Pendidikan Anak dalam Keluarga Perspektif Islam. Jurnal Pendidikan Agama Islam (Journal of Islamic Education Studies), 3(1), 109-136. https://doi.org/10.15642/jpai.2015.3.1.10 9-136

Ulwan, A. N. (2017). Pedoman Pendidikan Anake dalam Islam. As-Syifa Semarang.

Zuhrotunnisak, Z. (2018). Pengaruh Limgkemgan Keharna Terbadap Motivasi Belajar Pendidikean Agama Islam Siswa SMP Ma'arif NU Bampuputib Batang [Universitas Wahid Hasyim Semarang. http://eprints.unwahas.ac.id/1284/

Zulhaini, Z. (2019). Peranan Keluarga dalam Menanamkan Nilai-nilai Pendidikan Agama Islam kepada Anak. Al-Hikmah Jumnal Pendidikan dan Pendidikan Agama Islam), 1(1), 1-15. http://ejoumaluniks.ac.id/index.php/Alhikmah/ar ticle/view/57 